\title{
FIRM-SPECIFIC DETERMINANTS OF AN SME'S DECISION TO WITHDRAW FROM EXPORT ACTIVITY
}

Aleksandra Wasowska*

\begin{abstract}
Background. Although international business literature is focused on growth, the process of internationalisation is non-linear and not necessarily "forward-moving." Recently, there have been numerous calls for studies that would increase the understanding of the phenomenon of "de-internationalisation."
\end{abstract}

Research aims. This study investigates the firm-specific determinants of the SMEs' decisions to withdraw from export activity.

Methodology. Logistic regression analysis was used to examine the sample of 4105 independent SMEs from EU-28.

Key findings. High perceived barriers to internationalisation increase the likelihood of export withdrawal, while firm size and firm performance decrease the likelihood of export withdrawal.

Keywords: de-internationalisation, export withdrawal, escalation of commitment, SMEs, Europe.

\section{INTRODUCTION}

International business (IB) literature is typically focused on international growth. This is perhaps due to the fact that most popular models of internationalisation, such as the Uppsala model (Johanson \& Vahlne, 1977, 2009) are forward-moving, and imply that internationalisation is "the process of increasing involvement in international operations" (Welch \& Luostarinen, 1988, p. 36). However, internationalisation is a risky and demanding strategy, which often fails (e.g. Bianchi

\footnotetext{
" University of Warsaw. E-mail: awasowska@wz.uw.edu.pl
} 
\& Ostale, 2006), resulting in a complete or partial withdrawal from foreign markets. Moreover, internationalisation is not necessarily linear (Visaak \& Zhang, 2016). Oesterle (1997) suggests that firms may undergo "epochs" of internationalisation, followed by consolidation or even retrenchment. They may also experience "episodes" of rapid internationalisation or de-internationalisation. Welch \& Welch (2009) point to the fact that some companies withdraw from foreign operations and, after a certain period of "time-out", re-enter foreign markets.

While internationalisation is definitely not a unidirectional phenomenon (Trapczyński, 2016), most empirical work in IB focused on the antecedents and outcomes of the decisions involving increased commitment to foreign markets. Thus, there are numerous studies investigating export propensity (e.g. Zhao \& Zhu, 2002), internationalisation speed (Acedo \& Jones, 2007), degree of internationalisation (e.g. Zhao \& Zhu, 2002), entry mode choices (e.g. Laufs et al., 2016), performance outcomes of internationalisation (e.g. Lu \& Beamish, 2001), etc. Conversely, decisions involving the reduction of international commitment remain relatively understudied (Trapczyński, 2016). Little is known, for example, about the antecedents of the decisions to withdraw from export activity, although Bell \& Young (1998) suggest that factors influencing a firm's forward and backwards movements along the internationalisation process differ. Due to the early stage of development of the "de-internationalisation" research stream, existing studies are often qualitative or focused on presenting descriptive statistics. Very few studies on export withdrawal have tested theory-driven hypotheses. Moreover, existing studies rarely focused on de-internationalisation choices made by SMEs. Therefore, the objective of our paper is to contribute to this emerging research stream by investigating the firm-specific determinants of SME's decision to withdraw from export activity. Specifically, we ask the following question: what is the relationship between the firm size, performance, perceived barriers to internationalisation and the likelihood of export withdrawal by SMEs? In order to answer this question we conduct a quantitative study based on a sample of 4105 European SMEs.

The paper is structured as follows. We first provide a theoretical background of our work, presenting the conceptualisation of the phenomenon under study (i.e. de-internationalisation), discussing the findings of the existing studies on export withdrawal and formulating 
our research hypotheses. Then, we present the research methods. We follow with a presentation of our research findings. The last section, discussion and conclusions, provides theoretical and practical implications of our findings.

\section{BACKGROUND}

\section{The concept of de-internationalisation}

The phenomenon of de-internationalisation had long been overlooked by IB scholars. Initially, withdrawals from foreign markets were seen as failures (Seringhaus, 1987). The term "de-internationalisation" was introduced by Welch \& Luostarinen (1988, p. 37), who observed that "once a firm has embarked on a process, there is no inevitability about its continuation." In a study of Italian companies, Bonaccorsi (1992) revealed that the majority of exporters experienced at least temporal exits from foreign markets. He argued that foreign market exits should be conceptualised in the literature. The first attempt to theoretically conceptualise de-internationalisation was undertaken by Benito \& Welch (1997), who defined this phenomenon as "any voluntary or forced actions that reduce a company's engagement in or exposure to current cross-border activities." Other conceptualisations of the phenomenon of de-internationalisation followed. Mellahi (2003, p. 151) defined de-internationalisation as "a voluntary process of decreasing involvement in international operations in response to organisational decline at home or abroad, or as a means of enhancing corporate profitability under non-crisis conditions." Turcan (2003) developed a framework of a small firm's withdrawal process. The framework includes three fundamental concepts: (1) commitment of entrepreneurs, shaped by psychological, project, social and structural factors; (2) strategic change in dyadic network, often triggered by a critical event, and (3) time experienced by entrepreneurs. Turner (2012) examined the process of de-internationalisation of MNCs, using the lens of co-evolutionary theory. He argued that the phenomenon is a result of interaction between different parts of the corporation (e.g. subsidiaries) and the co-evolution between these parts and their environments. He underlined the fact that de-internalisation is shaped by both discretionary and deterministic forces. 
Reiljan (2004) classified de-internationalisation motives into four groups: (1) lack of international experience (e.g. insufficient analysis prior to internationalisation, too rapid and/or too early expansion, lack of knowledge, inappropriate choice of target market and/or operation mode, product misfit, insufficient attention paid to foreign markets), (2) change in strategy (e.g. focusing on the core market and/or core activities, change of owner's strategy, new management team, increase in domestic demand, decrease of the growth rate in the foreign markets, scarcity of resources), (3) poor performance and increase in costs (e.g. increase of transportation cost, increase in production cost, increased competition) (4) other (e.g. external shocks, due to governmental interventions).

The concept of de-internationalisation encompasses a number of strategic decisions, such as reductions relating to operation modes (e.g. reduction of commitment to a given market, plant or unit divestment or closures), reductions of the number of foreign markets (e.g. export withdrawal), reductions of the number of products offered in foreign markets (e.g. product withdrawal from a foreign market), as well as reductions of foreign value-adding activities and reductions of integration of international operations (i.e. reduction of subsidiary integration) (Trapczyński, 2016). Moreover, it may involve a complete withdrawal from all foreign markets, or only a reduction of the number of markets served and / or reduction of commitment to these markets (Visaak \& Zhang, 2016).

Export withdrawal may be defined as a "firm's strategic decision to remove a product/market combination from its international portfolio" (Pauwels \& Mathyssens, 1999, pp. 10-11). Export withdrawal may be forced (e.g. expulsion from a foreign country, due to political reasons) or strategic. The latter may have many reasons, both internal (e.g. new opportunities, changing company's priorities) and external (e.g. changing competitive environment).

Foreign market exit is often associated with a failure (Benito \& Welch, 1997). Internationalisation, defined broadly as "the process of adapting a firm's operations (strategy, structure, resources, etc.) to foreign markets" (Calof \& Beamish, 1995, p. 116) encompasses both increases and decreases in the firm's involvement to foreign markets (Chetty \& Campbell-Hunt, 2003). From this perspective, a withdrawal from a foreign market may be seen as an attempt to adapt to altered environmental conditions (e.g. increased level of competition, unfavourable economic conditions in the foreign market) (Benito \& Welch, 1997). 
Conversely, failure in exporting is not necessarily equal to export withdrawal, as many unsuccessful exporters stay the course. As observed by Benito \& Welch (1997, p. 13), "for highly committed managers, and when international markets are critical to the company's survival, complete withdrawal would be viewed as almost inconceivable." Pauwels \& Mathyssens (1999) developed a model of export withdrawal, indicating that this process is shaped by three forces: (1) escalation of market commitment (inhibitor), (2) exogenous stress (accelerator) and (3) confrontation between these two, fitting the "politics and power" type of decision-making (arbitrator).

Escalation of market commitment is therefore the underlying psychological mechanism responsible for the tendency to continue on a chosen strategy (Ghemawat, 1991), and more specifically, to stay in particular markets (Pauwels \& Mathyssen, 1999). Among the key drivers of persistence there are: overconfidence, sunk costs, perceived need for self-justification, denial, social costs of admitting failure, completion effects and exit barriers / organisational entrenchment (Drummond, 2014). Overconfidence is a human's tendency to overestimate one's abilities (e.g. in predicting future market trends). In the IB context, it is often an underlying reason for failed international expansion. For example, Tesco managers were very confident about their prospects in the U.S., despite the fact that British retailers typically failed in this market (Drummond, 2014). Also, for exporters it is often to stay in the foreign markets, due to the overconfidence about their chances to succeed.

Sunk costs are another reason to "stay the course," no matter the outcome. The more costs had a project (e.g. foreign expansion) generated, the more "psychologically" difficult it becomes to abandon it. Thus, according to the self-justification theory, managers tend to continue investing in such projects, in order to prove themselves and others that their decisions were correct. This is crucial, as the costs of admitting failure (especially publicly) are high. The mechanism of denial (another driver of escalation of commitment) makes them ignoring negative experience, and paying excessive attention to positive signals from the market and the organisation itself. Even if the failure is acknowledged, quitting a project may be costly, either financially or emotionally. Thus, the "completion effect" is another mechanism driving the escalation of commitment (Drummond, 2014). Finally, escalation may be caused by high exit barriers (e.g. major upheaval which would result from full de-internationalisation) (Benito \& Welch, 1997). 
Despite the numerous "forces for persistence," the escalation of commitment may be broken, since there are also many "orces for abandonment," such as aversion to loss, exhibited by managers (i.e. preferring to avoid losses than realise gains), opportunity costs (i.e. awareness of opportunities other than currently realised), perceived risk of persistence (i.e. increase in the perceived risk of the current project), managers' intolerance of failure (i.e. willingness to be seen as acting rationally), publicly stated limits (i.e. investment limits publicly announced, e.g. by listed companies), reluctance to renew budgets (i.e. reaching the limit of the investment budget) and shifting tides of organisation (e.g. new management team) (Drummond, 2014). These forces are likely to conduct to de-escalation, i.e., in this case, export withdrawal. For example, Benito \& Welch (1997) argue that managerial succession increases the likelihood of export withdrawal, as new managers are psychologically resistant to decisions and commitments made in the past (Benito \& Welch, 1997). Moreover, export withdrawal is more likely if alternative opportunities exist.

Benito \& Welch (1997) argue that the probability of de-internationalisation decreases as the commitment to foreign markets increases. Thus, export withdrawals are particularly frequent among early exporters. This is due to the high level of perceived export barriers, as well as a low commitment of managers to international activity (Benito \& Welch, 1997). Also, de-internationalisation is more common for export than other, more advanced modes of foreign market entry (Pauwels \& Mathyssen, 1999).

\section{Review of empirical studies on export withdrawal}

In a comprehensive review of de-internationalisation research, covering 66 papers published in peer-reviewed journals, printed materials, books, and electronic sources, Trapczyński (2016) identified a very limited number of studies on export withdrawals. Below, we review the findings of these studies.

Crick (2004), based on a qualitative study of 24 SMEs from the UK clothing industry, which had discontinued export activities, investigated the reasons for export withdrawal and the perception of assistance that would help the firms to recommence their overseas activity. $\mathrm{He}$ found that the firms could be classified into two types: disinterested exporters and disappointed exporters. Disinterested firms, before 
discontinuing exports, typically had only a marginal commitment to foreign markets. After withdrawal, they focused on domestic market and were not interested to recommence overseas operations. Disappointed firms were typically more experienced exporters, who, after withdrawal, were hoping to recommence their export activity as soon as possible and were receptive to public policy assistance. In another paper, Crick (2002) reports the results of a quantitative study on a sample of 50 firms from the UK clothing industry and 60 firms from the UK electronics industry. He found statistically significant differences between disinterested exporters and disappointed exporters in terms of the perception of issues affecting their decision to discontinue exporting and the need for public policy assistance.

In the follow-up study, Crick (2003) conducted a qualitative research on 21 firms which had discontinued exports. He investigated the behaviour of "disinterested" and "disappointed" firms after export withdrawal and found three patterns of such behaviour. First, a significant group of studied companies, "domestic players" (7 disinterested firms and 4 disappointed firms) remained in the domestic market and did not consider exporting as an option. Second, there was a group of "reluctant marginal players in overseas markets" (2 disinterested firms and 5 disappointed firms), which, while treating the domestic market as a strategic priority, were reacting to occasional orders from abroad and were eager to re-establish regular overseas activities. Third, three disappointed firms, instead of operating their exports from the UK, had opened subsidiaries in low-cost countries.

Girma et al. (2003) investigated both the antecedents and implications of export withdrawals by UK firms. They revealed that firms that decided to cease their export activity were typically smaller (both in terms of output and employment) and less productive than those which continued exporting. Moreover, they found that export withdrawals resulted in a decrease in output, employment, and shortterm productivity.

Pauwels and Mathyssens (2004) conducted a comparative study of 12 cases of export withdrawal, covering European medium-sized firms and MNCs. While they neither investigated the antecedents nor the performance outcomes of this phenomenon, they provided insight into the process of export withdrawal treated as a possible manifestation of strategic flexibility in the international expansion of the firm. They found that strategic flexibility does not always materialise with export 
withdrawal. If it does, it results from the creation of new strategic options at middle levels of the organisation and political processes leading to challenging the "old" export strategy and replacing it with the newly-generated strategic option.

Sabuhoro et al. (2006), based on a study of Canadian firms, revealed that the size of the establishment, the number of exported products and destinations, as well as the proportion of establishments entering an export episode were negatively related to the likelihood of export withdrawal. Moreover, belonging to a multi-plant enterprise increased the likelihood of export withdrawal.

Reiljan (2006), based on a comparative case study of 3 Estonian firms, indicated three reasons for market exits: lack of international experience, influence of foreign ownership, and changes in strategy. The same author conducted a study of 65 firms from the Estonian wood sector (Reilian, 2007). She revealed that $40 \%$ of the studied firms experienced an episode of export withdrawal and that withdrawals were more common for less innovative firms.

Ilmakunnas and Nurmi (2010) in their study of Finnish manufacturing plants found that the probability of export withdrawal decreased with the company's size, productivity, and capital intensity and increased with the company's age, the average employee age, and a high share of employees with technical education. The effects of foreign ownership on export withdrawal were contingent upon the size of the plant. For smaller plants (with 50 employees or fewer), foreign ownership had a positive influence on the likelihood of export withdrawal, while for larger plants (over 50 employees), this effect was negative. The employment share of exporters in the same industry had a negative influence on the likelihood of export withdrawal.

Engel et al. (2010), based on a study of French exporters, revealed that more productive firms, as well as firms with financial or corporate shareholders, were less likely to withdraw from export activity. They also observed a negative effect of a foreign corporate owner on the likelihood of export withdrawal. Moreover, both the current liability ratio and the non-current liability ratio increased the likelihood of export withdrawal, thus indicating the role of an overall poor financial performance in the decision to stop exporting. Firm size was found to be insignificant in the decision of export withdrawal.

The extant literature on export withdrawal is relatively scarce and yields two important knowledge gaps. First, there is a paucity 
of studies testing theory-driven research hypotheses. Second, the studied samples are very heterogeneous, i.e. they encompass firms of different sizes (small, medium, large enterprises) and ownership structures (independent companies, subsidiaries of domestic corporations, subsidiaries of MNCs). There is a scarcity of studies addressing the issue of export withdrawals by SMEs. In order to address these gaps, we conducted a study driven by the literature on the escalation of commitment, focusing on a large, multi-country sample of independent SMEs.

IB literature points to unique characteristics of SMEs, shaping their internationalisation process. Since SMEs are less diversified than large MNCs, they are more vulnerable to market, product, or technological changes (Buckley, 1989). Moreover, they suffer from the "liability of smallness," arising from the lack of economies of scale, a weak bargaining position towards business partners and a limited access to resources and capabilities (Ebben \& Johnson, 2005). These factors make them more exposed to exogenous stresses, which may accelerate the decision to withdraw from a foreign market (Pauwels \& Mathyssens, 1999). Conversely, in small firms, the decision-making process is less complex than in large corporations, as the owner-manager is typically the key decision-maker. Moreover, decision-makers of SMEs are less dependent on external influences (e.g. on corporate owners or other shareholders) and enjoy more managerial discretion (Hambrick \& Finkelstein, 1987). Therefore, they may be less prone to "persistence forces" such as the need for self-justification and social costs of admitting failure (Drummond, 2014).

Since the "liability of smallness" increases the exposure to exogenous stresses (accelerator) and the agility of SMEs reduces the escalation of commitment (inhibitor), we argue that smaller firms are more likely to discontinue their internationalisation strategy and withdraw from foreign markets. Therefore, we formulate the following hypothesis:

Hypothesis 1 . Firm size is negatively related to the likelihood of export withdrawal.

Other than firm size, firm performance is another factor that is likely to have an impact on both the accelerator and inhibitor of escalation of commitment. Persistence to the current strategy will be more likely for high-performing firms, since they will be less 
vulnerable to external shocks. Conversely, low-performing firms will be subject to a number of forces for abandonment, such as aversion to loss, opportunity costs, perceived risk of persistence, and managers' intolerance of failure (Drummond, 2014). Therefore, we formulate the following hypothesis:

Hypothesis 2. Firm performance is negatively related to the likelihood of export withdrawal.

Pauwels et al. (2009), building on the Theory of Planned Behaviour (Ajzen, 1991) find that the decision-maker's attitude towards internationalisation has an impact on the decision to persist in the foreign market. One of the key determinants of the decision-maker's attitude towards foreign markets, and consequently, of the international behaviour of firms, is the perception of export barriers (Artega-Ortiz \& Fernandez-Ortiz, 2010). Leonidou (1995, p. 31) defines export barriers as "any attitudinal, structural, operative, or other obstacles that hinder or inhibit companies from taking the decision to start, develop, or maintain international activity." Thus, the perception of export barriers affects strategic decisions at every stage of the "internationalisation lifecycle," i.e. at the pre-export phase (decision whether to start exporting or focus on the domestic market), export phase (decisions regarding the export scale, scope, and pace, decisions whether to continue exporting or withdraw from the export market), as well as post-export phase (decision whether to recommence exporting or stay focused on the domestic market only). We argue that decision-makers perceiving barriers to internationalisation as high will be less likely to continue their commitment to foreign markers. Therefore, we formulate the following hypothesis:

Hypothesis 3. Perceived barriers to internationalisation are positively related to the likelihood of export withdrawal.

The proposed relationships are presented in Figure 1. 


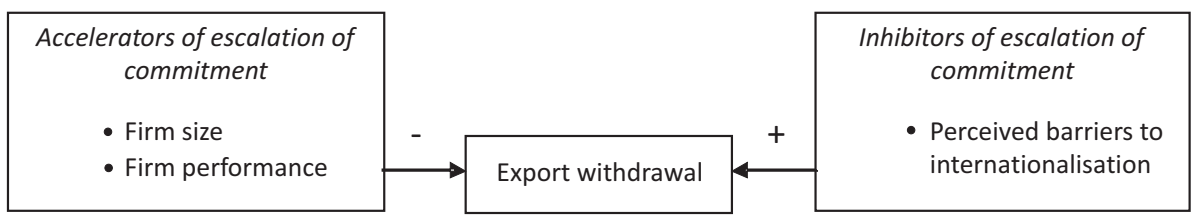

$\mathrm{H} 1, \mathrm{H} 2$

H3

Figure 1. Analytical framework

Source: own elaboration.

\section{METHOD}

This study is based on data from the Flash Eurobarometer survey, conducted in June 2015 by TNS Political \& Social, at the request of the European Commission (2015). The survey was focused on internationalisation and covered 14,513 SMEs from $28 \mathrm{EU}$ countries and 6 non-EU countries. Respondents (top executives with decision-making responsibilities, e.g. CEO, general manager, financial director) were interviewed with the use of CATI.

From the original database, we select companies experienced in exporting. We exclude companies from non-European countries, as well as "dependent" companies (i.e. subsidiaries of MNCs). The rationale for excluding "dependent" companies, i.e. subsidiaries of large corporations, is that, due to their ownership structure, they tend to "behave like large ones" and achieve higher level of internationalisation (Airaksinen et al., 2015). Moreover, corporate ownership has been found to greatly influence an internationalisation strategy, including the decisions on export withdrawal (Engel et al., 2010). Therefore, in order to exclude this effect, we study independent SMEs only. Our final sample is composed of 4,105 independent SMEs from EU-28, with experience in exporting. Detailed characteristics of our research sample (including the descriptive statistics) is presented in Table 1.

Dependent variable (export withdrawal) is dichotomous ( 1 - yes, $0-$ no), measured using the following question: Have you ever exported, tried to export or considered exporting your products and/or services? The following answers: "You used to export but you stopped doing it" and "You tried, but you have given up" were treated as "export withdrawal" (these answers scored 1). Conversely, companies that had a continuous export experience (present exporters) scored 0. Thus, our dependent 
variable measures complete export withdrawals (as opposed to partial export withdrawal, which is not possible to measure using our database).

Barriers to internationalisation were measured with a 12 -item scale used in the Eurobarometer survey. Scale items included the following statements, assessed on a 3-point Likert scale ("major problem," "minor problem," "not a problem at all"): (1) Delivery costs are too high; (2) Your company does not know the rules which have to be followed (e.g. labelling); (3) Payments from other countries are not secure enough; (4) Dealing with foreign taxation is too complicated or too costly; (5) Your company lacks the language skills to deal with the foreign countries; (6) Your company's products and/or services are specific to your country's market; (7) Resolving cross-border complaints and disputes is too expensive; (8) your company does not have specialised staff to deal with exports; (9) Identifying business partners abroad is too difficult; (10) The administrative procedures are too complicated; (11) The financial investment is too large; (12) Your company does not know where to find information about the potential market. Although barriers to internationalisation are typically measured on a 7-point Likert scale, we acknowledge that for large, international projects, shorter scales are often preferred. Following Jacoby \& Mattell (1971), we accept a 3-point Likert scale as a "good enough" substitute for longer scales. We checked the reliability of our scale using the Cronbach's Alpha, which turned out to be satisfactory (Cronbach's Alpha $=0.838$, thus exceeds the recommended threshold of 0.7).

We measure firm size with the natural logarithm of the number of employees. In order to measure firm performance, we assess turnover growth, using a question: "Since January 2008/end of your company's first year of operation, please indicate the percentage by which your company's turnover has increased or decreased" and coded as follows: "risen by more than 25\%" - 5; "risen by between 5 and $25 \%$ " -4 ; "remained approximately the same" - 3; "fallen by between 5 and $25 \%$ " - 2 ; "fallen by more than $25 \%$ " - 1 .

We control for industry and firm age. In order to measure industry, we use dummy variables: manufacturing (NACE category C), retail (NACE category G), services (NACE categories $\mathrm{H}, \mathrm{I}, \mathrm{J}, \mathrm{K}, \mathrm{L}, \mathrm{M}, \mathrm{N}$ ) and industry (NACE categories $\mathrm{B} / \mathrm{D} / \mathrm{E} / \mathrm{F})$. Industry is not included in the regression model, as it represents a reference level for interpretation of the results for other industry variables. Firm age measured with a number of years since the firm's foundation. Given the multi-country nature of our sample, 
we also control for two country-level variables: market size (measured with the natural logarithm of population size) and economic development (measured with the natural logarithm of GDP per capita).

We acknowledge a large a debate, whether Likert-type scales (in our study used to measure export barriers and turnover growth) can be treated as interval and whether parametric methods are appropriate for the analysis of such data (e.g. Carifio \& Perla, 2008). In this paper we follow Norman's (2010) suggestion that Likert data is suitable for parametric tests. Since our dependent variable is dichotomous, we test the research hypotheses using a logistic regression analysis, a technique widely used in IB literature for modelling choices relating to internationalisation, e.g. the decision to start exporting, i.e. export propensity (e.g. Zhao \& Zou, 2002).

\section{RESULTS}

In Table 1 we present descriptive statistics for the variables used in the study.

Table 1. Descriptive statistics

\begin{tabular}{|l|c|c|}
\hline \multicolumn{1}{|c|}{ Continuous variables } & Mean & SD \\
\hline Firm age & 23.6741 & 21.80873 \\
\hline Firm size & 2.7049 & 1.28492 \\
\hline Firm performance & 4.38 & 1.571 \\
\hline Barriers to internationalisation & 1.5746 & 0.43923 \\
\hline Binary variables & Frequency & $\%$ of Total \\
\hline Industry & & \\
\hline Manufacturing & 1,392 & $33.9 \%$ \\
\hline Retail & 1,473 & $35.9 \%$ \\
\hline Services & 787 & $19.2 \%$ \\
\hline Industry & 453 & $11 \%$ \\
\hline Total & 4,105 & $100 \%$ \\
\hline Export withdrawal & & $8 \%$ \\
\hline Yes & 327 & $92 \%$ \\
\hline No & 3,778 & $100 \%$ \\
\hline Total & 4,105 & \\
\hline
\end{tabular}

Source: own calculations.

In table 2 we present the correlation matrix. 


\begin{tabular}{|c|c|c|c|c|c|c|c|c|c|}
\hline$\sigma^{\circ}$ & $\begin{array}{l}* \\
* \\
\vec{*} \\
\\
0 \\
0\end{array}$ & $\begin{array}{l}0 \\
0 \\
0 \\
0\end{array}$ & \begin{tabular}{l}
$*$ \\
$*$ \\
\multirow{*}{*}{} \\
0 \\
0
\end{tabular} & 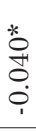 & 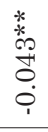 & \begin{tabular}{l}
$*$ \\
$*$ \\
\multirow{2}{*}{} \\
8 \\
0 \\
0 \\
1
\end{tabular} & $\begin{array}{l}* \\
* \\
\text { i. } \\
\text { ô } \\
\stackrel{0}{0} \\
0\end{array}$ & 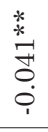 & $\neg$ \\
\hline$\infty$ & 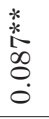 & 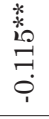 & $\begin{array}{l}\tilde{8} \\
\circ \\
\circ\end{array}$ & ¿. & 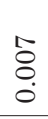 & 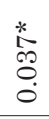 & $\begin{array}{l}\text { Nै } \\
\text { Oे } \\
\text { i }\end{array}$ & $\dashv$ & 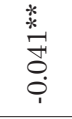 \\
\hline$\stackrel{\circ}{\circ}$ & 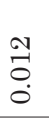 & 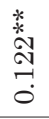 & $\begin{array}{l}* \\
* \\
\text { ov } \\
\infty \\
0 \\
0 \\
0\end{array}$ & $\begin{array}{l}\text { ". } \\
\text { \% } \\
0 \\
0 \\
0 \\
\end{array}$ & $\begin{array}{l}1 \\
8 \\
0 \\
0\end{array}$ & \begin{tabular}{l}
$*$ \\
$*$ \\
\multirow{2}{*}{} \\
0 \\
0 \\
-1 \\
0
\end{tabular} & -1 & $\begin{array}{l}\text { ⿵ै } \\
\text { ơ } \\
\stackrel{0}{1}\end{array}$ & 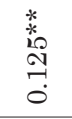 \\
\hline $0^{\circ}$ & \begin{tabular}{l}
$*$ \\
\multirow{2}{*}{} \\
0 \\
0 \\
$\dot{0}$
\end{tabular} & \begin{tabular}{l}
$*$ \\
\multirow{*}{*}{} \\
$\stackrel{0}{0}$ \\
\multirow{2}{*}{} \\
0 \\
0
\end{tabular} & $\begin{array}{l}0 \\
8 \\
0 \\
0 \\
\dot{0}\end{array}$ & 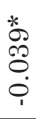 & $\begin{array}{l}* \\
* \\
\cdots \\
\cdots \\
0 \\
0 \\
0 \\
0\end{array}$ & $\neg$ & \begin{tabular}{l}
$*$ \\
\multirow{2}{*}{} \\
8 \\
0 \\
$\vdots$ \\
0
\end{tabular} & \begin{tabular}{l} 
炎 \\
\multirow{2}{0}{} \\
0 \\
0
\end{tabular} & $\begin{array}{l}* \\
* \\
0 \\
0 \\
0 \\
0 \\
0\end{array}$ \\
\hline $10^{\circ}$ & $\begin{array}{l}\stackrel{+}{8} \\
0 \\
\dot{0}\end{array}$ & $\begin{array}{l}* 0 \\
0 \\
0 \\
0 \\
0 \\
0\end{array}$ & 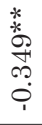 & 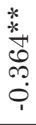 & - & 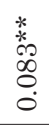 & 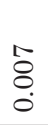 & $\begin{array}{l}5 \\
8 \\
0\end{array}$ & \begin{tabular}{l} 
* \\
\multirow{2}{*}{} \\
$\stackrel{9}{0}$ \\
$\stackrel{0}{0}$ \\
$\dot{0}$
\end{tabular} \\
\hline$\dot{+}$ & $\begin{array}{l}\text { * } \\
\text { * } \\
\stackrel{+}{*} \\
\text { o } \\
0 \\
1\end{array}$ & 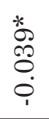 & $\begin{array}{l}* \\
* \\
* \\
0 \\
0 \\
10 \\
0 \\
0 \\
\end{array}$ & -1 & 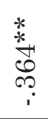 & 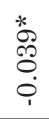 & 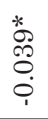 & $\stackrel{\overrightarrow{0}}{0}$ & $\begin{array}{l}\text { *. } \\
\text { O+ } \\
0 \\
0 \\
0\end{array}$ \\
\hline$\infty \dot{0}$ & $\begin{array}{l}* \\
* \\
* \\
\text { o. } \\
\text { Nै } \\
0 \\
0\end{array}$ & \begin{tabular}{l}
$*$ \\
\multirow{2}{*}{} \\
$\stackrel{0}{0}$ \\
$\stackrel{1}{0}$ \\
0
\end{tabular} & - & $\begin{array}{l}* \\
* \\
0 \\
0 \\
0 \\
0 \\
0 \\
0\end{array}$ & 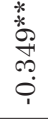 & $\begin{array}{l}0 \\
8 \\
0 \\
\dot{0}\end{array}$ & 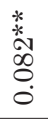 & $\stackrel{5}{\circ}$ & $\begin{array}{l}* \\
* \\
\stackrel{*}{*} \\
\vdots \\
0 \\
0\end{array}$ \\
\hline oi & 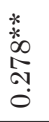 & $r$ & 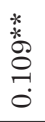 & 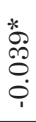 & 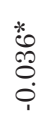 & 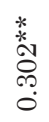 & 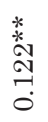 & 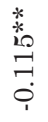 & $\begin{array}{l}0 \\
\stackrel{0}{0} \\
0\end{array}$ \\
\hline$\dot{r}$ & - & \begin{tabular}{l}
$*$ \\
$*$ \\
$\infty$ \\
\multirow{2}{*}{} \\
$\vdots$ \\
0
\end{tabular} & 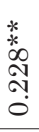 & $\begin{array}{l}\text { * } \\
\text { * } \\
\text { O } \\
\text { N } \\
0 \\
1\end{array}$ & $\begin{array}{l}\text { ¿ } \\
8 \\
0 \\
i\end{array}$ & 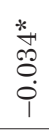 & $\begin{array}{l}\text { जै } \\
\stackrel{0}{0} \\
0\end{array}$ & \begin{tabular}{l}
$*$ \\
\multirow{2}{*}{} \\
$\infty$ \\
$\stackrel{0}{0}$ \\
$\stackrel{0}{0}$
\end{tabular} & 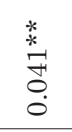 \\
\hline & 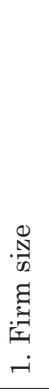 & 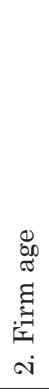 & 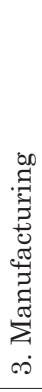 & 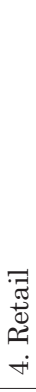 & 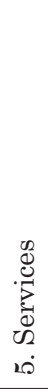 & 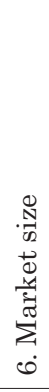 & 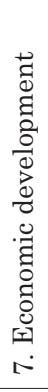 & 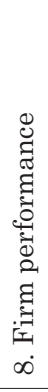 & 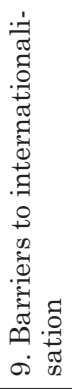 \\
\hline
\end{tabular}


In Table 3 we present the results of logistic regression analysis. Hypothesis 1 predicts a negative relationship between firm size and export withdrawal. We find support for this hypothesis, i.e. firm size decreases the likelihood of export withdrawal $(p<0.001)$.

Hypothesis 2 predicts a negative relationship between firm performance and export withdrawal. We find support for this hypothesis, i.e. high performance decreases the likelihood of export withdrawal $(\mathrm{p}<0.001)$.

Hypothesis 3 predicts a positive relationship between perceived barriers to internationalisation and export withdrawal. We find support for this hypothesis, i.e. high perceived barriers to internationalisation increase the likelihood of export withdrawal $(p<0.001)$.

Table 3. Logistic regression analysis

\begin{tabular}{|l|c|c|c|c|c|}
\hline & B & SE & Wald & Df & Significance \\
\hline Firm size & -0.343 & 0.052 & 43.167 & 1 & 0.000 \\
\hline Firm age & 0.007 & 0.003 & 4.516 & 1 & 0.034 \\
\hline Manufacturing & -1.130 & 0.174 & 42.008 & 1 & 0.000 \\
\hline Retail & -1.283 & 0.173 & 54.992 & 1 & 0.000 \\
\hline Services & -0.804 & 0.188 & 18.300 & 1 & 0.000 \\
\hline Economic development & -0.660 & 0.115 & 32.812 & 1 & 0.000 \\
\hline Market size & 0.107 & 0.053 & 4.054 & 1 & 0.044 \\
\hline Firm performance & -0.168 & 0.037 & 21.100 & 1 & 0.000 \\
\hline $\begin{array}{l}\text { Barriers to internationalisa- } \\
\text { tion }\end{array}$ & 1.002 & 0.127 & 62.311 & 1 & 0.000 \\
\hline Constant & 3.906 & 1.190 & 10.773 & 1 & 0.001 \\
\hline -2Log Likelihood & 2040.366 & - & - & - & - \\
\hline Nagelkarke R2 & 0.134 & - & - & - & - \\
\hline Chi-square & 241.486 & - & - & - & 0.000 \\
\hline Correct classification (\%) & $92 \%$ & - & - & - & - \\
\hline Hosmer and Lemeshow test & 9.877 & - & - & - & 0.274 \\
\hline
\end{tabular}

Source: own calculations. 


\section{DISCUSSION AND CONCLUSIONS}

This study aimed at investigating the firm-specific determinants of the SMEs' decisions to withdraw from export activity. We find that the likelihood of export withdrawal increases with the perceived barriers to internationalisation and decreases with the firm size and performance. Thus, we find support for our research hypotheses.

The results our study are in line with the findings of Girma et al. (2003), Sabuhoro et al. (2006) and Ilmakunnas and Nurmi (2010), who revealed the negative effect of company's size on the likelihood of export withdrawal of UK, Canadian and Finnish firms, respectively. Moreover, our findings concord with Engel et al. (2010) who pointed to the role of poor financial performance on the decision to stop exporting. While we have not identified studies investigating barriers to internationalisation as an antecedent of export withdrawal, we conclude that our findings are consistent with the results reported by Pauwels et al. (2009), regarding the role of the decision-maker's attitude towards internationalisation in the decision to persist in the foreign market.

Our paper contributes to the emerging "de-internationalisation" research stream by incorporating the literature on escalation of commitment (Ghemawat, 1991; Drummond, 1995, 2014) to the study of determinants of export withdrawal by SMEs. Based on this literature, we developed an analytical framework proposing a set of relationships between firm-specific characteristics and export withdrawal. We have tested these relationships based on a large, multi-country dataset. Our study sheds light on the determinants of export withdrawal, resulting from an interplay of accelerators (firm size, firm performance) and inhibitors (perceived barriers to internationalisation) of escalation of commitment.

Based on our study, we may formulate some practical implications. Following Pauwels \& Mathyssens (1999) we conclude that export withdrawal may be "a proactive decision that optimized a firm's international market portfolio." Therefore, managers, owners, and other stakeholders should not perceive the decision to withdraw from foreign markets as a failure. Conversely, both types of decisions in the internationalisation process (i.e. to increase or decrease commitment) should be treated as viable strategic options, depending on the conditions in the current markets (both foreign and domestic), as well as opportunities available in the currently served or other markets. 
Such a "positive" reframing of the concept of export withdrawal would serve as a remedy against escalation of commitment.

Our findings are tempered by some limitations. First, since we use cross-sectional data, we are unable to test the effects of the studied variables upon the likelihood of export withdrawal in a strict sense. There are conceptual arguments in favour of firm size, firm performance and perceived barriers to internationalisation affecting the decision to withdraw from exporting activity, the other causal direction is possible. For example, as the company decreases its scale of operations (as a result of export withdrawal), its performance indicators and number of employees may shrink. Also, the perceived barriers to internationalisation may increase only after the export withdrawal, as a result of "self-serving attributions" (Heider, 1958), i.e. the mechanism through which decision-makers attribute their failures (in this case: export withdrawal) to external causes, in order to protect their ego.

Second, since we used a large dataset developed within the Flash-Eurobarometer project, we faced limitations in terms of the measurement of our key variables. Further research on the determinants of export withdrawal, using more refined measures of barriers to internationalisation and performance, as well as a broader definition of export withdrawal (exit from some of the markets, instead of an exit from all foreign markets) is needed. Moreover, we encourage further research aimed at disentangling the relationships between these variables and export withdrawal, using longitudinal research designs.

\section{REFERENCES}

Acedo, F.J. \& Jones, M.V. (2007). Speed of internationalisation and entrepreneurial cognition: Insights and a comparison between international new ventures, exporters and domestic firms. Journal of World Business, 42(2), 236-252.

Airaksinen, A., Luomaranta, H., Alajääskö, P. \& Roodhuijzen, A. (2015). Statistics on small and medium-sized enterprises. Dependent and independent SMEs and large enterprises. Eurostat. [Online] Retrieved from: http://ec.europa. eu/eurostat/statistics-explained (access: 15.08.2016).

Ajzen, I. (1991). The Theory of Planned Behavior. Organizational behaviour and Human Decision Processes, 50(2), 179-211. 
Artega-Ortiz, J. \& Fernandez-Ortiz, R. (2010). Why don't we use the same export barrier measurement scale? An empirical analysis in small and medium-sized enterprises. Journal of Small Business Management, 48(3), 395-420.

Bell, J. \& Young, S. (1998). Towards an integrative framework of the internationalisation of the firm. In: G. Hooley, R. Loveridge \& D. Wilson (eds.), Internationalisation: Process, Context and Markets (pp. 5-28). London: Macmillan.

Benito, G. \& Welch, L.S. (1997). De-internationalisation. Management International Review, 37(2), 7-25.

Bianchi, C. \& Ostale, E. (2006). Lessons learned from unsuccessful internationalisation attempts: example of multinational retailers in Chile. Journal of Business Research, 59(1), 140-147.

Bonaccorsi, A. (1992). On the relationship between firm size and export intensity. Journal of International Business Studies, 23(4), 605-635.

Buckley, P. (1989). Foreign Direct Investment by Small and Medium Size Enterprise: The Theoretical Background. Small Business Economics, 1(2), 89-100.

Calof, J. \& Beamish, P. (1995). Adapting to foreign markets: explaining internationalisation. International Business Review, 4(2), 115-131.

Carifio, J. \& Perla, R. (2008). Resolving the 50-year debate around using and misusing Likert scales. Medical Education, 42(12), 1150-1152.

Chetty, S. \& Campbell-Hunt, C. (2003). Explosive international growth and problems of success among small to medium-sized firms. International Small Business Journal, 21(1), 5-27.

Crick, D. (2002). The decision to discontinue exporting: SMEs in two UK trade sectors. Journal of Small Business Management, 40(1), 66-77.

Crick, D. (2003). The international entrepreneurial decision of UK SMEs to discontinue overseas activities: a research note reporting practices within the clothing industry eighteen months on. Journal of International Entrepreneurship, 1(4), 405-413.

Crick, D. (2004). U.K. SME decision to discontinue exporting: an exploratory investigation of practices within the clothing industry. Journal of Business Venturing, 19(4), 567-581.

Drummond, H. (1995). De-escalation in decision-making: a case of disastrous partnership. Journal of Management Studies, 32(2), 265-281.

Drummond, H. (2014). Escalation of commitment: when to stay the course? Academy of Management Perspectives, 28(4), 430-446.

Ebben, J. \& Johnson, A. (2005). Efficiency, Flexibility, or Both? Evidence Linking Strategy to Performance in Small Firms. Strategic Management Journal, 26(13), 1249-1259. 
Engel, D., Procher, V. \& Schmidt, C.M. (2010). The asymmetries of a small world: entry into and withdrawal from international markets by French firms. Ruhr Economic Papers No. 192. Bochum: Ruhr-Universität Bochum (RUB).

European Commission (2015). Internationalisation of small and medium sized enterprises. Flash Eurobarometer 421.

Ghemawat, P. (1991). Commitment: The dynamic of strategy. New York: Free Press.

Girma, S., Greenaway, D. \& Kneller, R. (2003). Export market exit and performance dynamics: a causality analysis of matched firms. Economics Letters, 80(2), 181-187.

Hambrick, D.C. \& Finkelstein, S. (1987). Managerial discretion: A bridge between polar views of organizational outcomes. In: B.M. Staw \& L.L. Cummings (eds.), Research in Organizational Behavior, 9 (pp. 369-406). Greenwich, CT: JAI.

Heider, F. (1958). The psychology of interpersonal relations. New York: Wiley.

Ilmakunnas, P. \& Nurmi, S. (2010). Dynamics of export market entry and exit. Scandinavian Journal of Economics, 112(1), 101-126.

Jacoby, J. \& Mattell, M.S. (1971). Three-point Liker scales are good enough. Journal of Marketing Research, 8(4), 495-500.

Johanson J. \& Vahlne J.-E. (1977). The internationalisation process of the firm - a model of knowledge development and increasing foreign market commitments. Journal of International Business Studies, 8(1), 23-32.

Johanson, J. \& Vahlne, J.-E. (2009). The Uppsala Internationalisation Process Model Revisited - from liability of foreignness to liability of outsidership. Journal of International Business Studies, 40(9), 1411-1431.

Laufs, K., Bembom, M. \& Schwens, Ch. (2016). CEO characteristics and SME foreign market entry mode choice: The moderating effect of firm's geographic experience and host-country political risk. International Marketing Review, 33(2), 246-275.

Leonidou, L.C. (1995). Empirical research on export barriers: review, assessment, and synthesis. Journal of International Management, 3(1), 29-43.

Lu, J. \& Beamish, P. (2001). The internationalisation and performance of SMEs. Strategic Management Journal, 22(6-7), 565-586.

Mellahi, K. (2003). The de-internationalisation process: A case study of Marks \& Spencers. In: C. Wheeler, F. McDonald \& I. Greaves (eds.), Internationalisation: Firms strategies and management (pp. 150-162). New York: Palgrave.

Norman, G. (2010). Likert scales, levels of measurement and the "laws" of statistics". Advances in Health Sciences Education, 15(5), 625-632.

Oesterle, M.-J. (1997). Time-span until internationalisation: foreign market entry as a built-in mechanism of innovations. Management International Review, 37(2), 125-149. 
Pauwels, P. \& Matthyssens, P. (2004). Strategic flexibility in export expansion: growing through withdrawal, International Marketing Review, 21(4/5), 496-510.

Pauwels, P. \& Mathyssens, P. (1999). A strategy process perspective on export withdrawal. Journal of International Marketing, 7(3), 10-37.

Pauwels, P., Patterson, P., de Ruyter, K. \& Wetzels, M. (2009). The Propensity to Continue Internationalisation: A Study of Entrepreneurial Decision-Making in Australian Service Firms. Advances in International Marketing, 20, 11-36.

Reiljan, E. (2006). The role of entrepreneurial actions in the de-internationalisation of Estonian enterprises: entrepreneurs' perceptions. In: T. Mets, J. Andrijevskaja, U. Venesaar \& E. Kolbre (eds.), Entrepreneurship in Estonia: Policies, Practices, Education and Research, 28, 139-153.

Reiljan, E. (2007). The role of cooperation and innovation in reducing the likelihood of export withdrawals. Journal of East-West Business, 13(2), 243-261.

Reiljan, E. (2004). Reasons for De-internationalisation. An Analysis of Estonian Manufacturing Companies, Dissertation. Tartu: University of Tartu.

Sabuhoro, J.B., Larue, S.B. \& Gervais, Y. (2006). Factors determining the success or failure of Canadian establishment on foreign markets: a survival analysis approach. The International Trade Journal, 20(1), 33-73.

Seringhaus, F.H.R. (1987). Do experienced exporters have market entry problems? The Finnish Journal of Management, 4, 376-388.

Trapczyński, P. (2016). De-internationalisation. A review of empirical studies and implications for international business research. Baltic Journal of Management, 11(4), 350-379.

Turcan, R.V. (2003). De-internationalisation and the Small Firm. In: C. Wheeler, F. McDonald \& I. Greaves (eds.), Internationalisation: Firms strategies and management (pp. 208-222). NewYork: Palgrave.

Turner, C. (2012). De-internationalisation: towards a co-evolutionary framework. European Business Review, 24(2), 92-105.

Visaak, T. \& Zhang, X. (2016). A born global's radical, gradual and nonlinear internationalisation: a case from Belarus. Journal of East European Management Studies, 21(2), 209-230.

Welch, C. \& Welch, L. (2009). Re-internationalisation: exploration and conceptualisation. International Business Review, 18(6), 567-577.

Welch, L.S. \& Luostarinen, R. (1988). Internationalisation: evolution of a concept. Journal of General Management, 14(2), 34-55.

Zhao, H. \& Zou, S. (2002). The Impact of Industry Concentration and Firm Location on Export Propensity and Intensity: An Empirical Analysis of Chinese Manufacturing Firms. Journal of International Marketing, 10(1), 52-71. 


\section{ORGANIZACYJNE UWARUNKOWANIA DECYZJI MAKYCH I ŚREDNICH PRZEDSIĘBIORSTW O WYCOFANIU SIĘ Z EKSPORTU}

\section{Abstrakt}

Tło badań. Badania z zakresu biznesu międzynarodowego skupiają się na wzroście firmy. Proces umiędzynarodowienia nie jest jednak linearny i nie zawsze przebiega „w przód”. W ostatnim czasie w literaturze zwraca się uwagę na konieczność lepszego zrozumienia zjawiska dezinternacjonalizacji.

Cel badań. Celem artykułu jest zbadanie organizacyjnych uwarunkowań decyzji o wycofaniu się z eksportu, podejmowanych przez małe i średnie przedsiębiorstwa.

Metodologia. W badaniu zastosowano analizę regresji logistycznej, przeprowadzonej na próbie 4105 małych małych i średnich przedsiębiorstw z 28 krajów należących do Unii Europejskiej.

Kluczowe wnioski. Wysokie postrzegane bariery umiędzynarodowienia są pozytywnie związane z prawdopodobieństwem wycofania się z eksportu. Prawdopodobieństwo wycofania się z eksportu spada wraz z wielkością i wynikami finansowymi firmy.

Słowa kluczowe: dezinternacjonalizacja, wycofanie się z eksportu, eskalacja zaangażowania, małe i średnie przedsiębiorstwo, Europa. 